\title{
Englerin A-sensing charged residues for transient receptor potential canonical 5 channel activation
}

\author{
SeungJoo Jeong 1,\#, Juyeon Ko 1,\#, Minji Kim²,\#, Ki Chul Park, ", Eunice Yon June Park', Jinsung Kim', Youngjoo Baik', \\ Jinhong Wie ${ }^{4}$, Art E. Cho ${ }^{3}$, Ju-hong Jeon ${ }^{1}$, and Insuk So,* \\ ${ }^{1}$ Department of Physiology, Seoul National University College of Medicine, Seoul 03080, ${ }^{2}$ College of Veterinary Medicine, Chungnam National University, Dae- \\ jeon 34134, ${ }^{3}$ Department of Bioinformatics, Korea University, Sejong 30019, ${ }^{4}$ Department of Biology, University of Pennsylvania, Philadelphia, PA 19104, USA
}

\section{ARTICLE INFO}

Received October 9, 2018

Revised March 25, 2019

Accepted March 26, 2019

*Correspondence

Insuk So

E-mail:Insuk@snu.ac.kr

\section{Key Words}

Englerin A

Ion channels

Mutant proteins

Transient receptor potential canonical 5

\#These authors contributed equally to this work.
ABSTRACT The transient receptor potential canonical (TRPC) 5 channel, known as a nonselective cation channel, has a crucial role in calcium influx. TRPC5 has been reported to be activated by muscarinic receptor activation and extracellular $\mathrm{pH}$ change and inhibited by the protein kinase $C$ pathway. Recent studies have also suggested that TRPC5 is extracellularly activated by englerin A (EA), but the mechanism remains unclear. The purpose of this study is to identify the EA-interaction sites in TRPC 5 and thereby clarify the mechanism of TRPC 5 activation. TRPC 5 channels are over-expressed in human embryonic kidney (HEK293) cells. TRPC5 mutants were generated by site-directed mutagenesis. The whole-cell patch-clamp configuration was used to record TRPC5 currents. Western analysis was also performed to observe the expression of TRPC 5 mutants. To identify the EA-interaction site in TRPC5, we first generated pore mutants. When screening the mutants with EA, we observed the EAinduced current increases of TRPC5 abolished in K554N, H594N, and E598Q mutants. The current increases of other mutants were reduced in different levels. We also examined the functional intactness of the mutants that had no effect by EA with TRPC 5 agonists, such as carbachol or GTP $\gamma$ S. Our results suggest that the three residues, Lys-554, His-594, and Glu-598, in TRPC5 might be responsible for direct interaction with $E A$, inducing the channel activation. We also suggest that although other pore residues are not critical, they could partly contribute to the EA-induced channel activation.

\section{INTRODUCTION}

The transient receptor potential (TRP) channels are known to play a significant role in intracellular calcium regulation. We have previously reported that among TRP families, the TRP canonical (TRPC) 5 channel is crucial not only in calcium regulation, but also extracellular $\mathrm{pH}$ sensing [1]. We have identified that the G-protein coupled receptors (GPCR) pathway induces TRPC5 activation independent from the activation by the trivalent cat- ions, $\mathrm{La}^{3+}$ and $\mathrm{Gd}^{3+}[2,3]$. The potentiation of TRPC5 is reported to be enhanced by several different factors, such as extracellular phospholipids [4], heavy metals [5], oxidized glutathione [6], and nitric oxide [7], and desensitized by protein kinase C-mediated phosphorylation [8].

Englerin A (EA) is a novel natural product that selectively inhibits the growth of renal cell carcinoma cell lines [9]. Recently, it has been used as an activator of TRPC4 and TRPC5 channels. A recent study reported that G-protein signaling does not take part (i) This is an Open Access article distributed under the terms of the Creative Commons Attribution Non-Commercial License, which permits unrestricted non-commercial use, distribution, and reproduction in any medium, provided the original work is properly cited. Copyright @ Korean J Physiol Pharmacol, pISSN 1226-4512, eISSN 2093-3827
Author contributions: S.J. designed the study, generated figures, wrote the manuscript, analyzed data and performed electrophysiological experiments. J.Y.K. generated mutant constructs used, performed surface biotinylation experiments and generated figures. M.K. generated mutant constructs used. E.Y.J.P. helped to correct English in writing the overall manuscript. J.S.K. performed electrophysiological experiments for permeability change to monovalent cations. K.P., Y.B., J.W., and A.E.C. provided technical supports. J.J. and I.S. discussed the results and their implications, and commented on the manuscript at almost all stages. 
in the channel activation by EA [9]. The study also uncovered that the application of EA on TRPC4 or 5-overexpressed human embryonic kidney (HEK) cells activates the channels and induces cell death in consequence of increasing intracellular calcium levels [9]. Such results were supported by our previous studies where we reported $\mathrm{G \alpha}_{\mathrm{i}}$, oxidized glutathione and constitutively active mutant of TRPC4, 5 increased intracellular $\mathrm{Ca}^{2+}[3,6,10]$ and used TRPC4-GCaMP6 to find that EA increased calcium levels near TRPC4 channels [11]. However, the mechanism of EA-induced activation of the ion channels is unclear. A report suggests that the phenyl ring in EA plays a significant role in the activation of the L-type calcium channel [12]. In the present study, we have identified the EA-interaction sites in TRPC5 using a patch clamp technique by which we recorded the EA-induced current increases of TRPC5 mutants. The present study provides a plausible and novel mechanism of TRPC 5 channel activation.

\section{METHODS}

\section{Cell culture and transient transfection}

Human embryonic kidney (HEK293) cells (ATCC, Manassas, VA, USA) were maintained according to the supplier's recommendations. For transient transfection, cells were seeded in 12well plates. The following day, $0.5 \mu \mathrm{g} /$ well of pcDNA vector containing the cDNA for TRPC5-EGFP was transfected into the cells using the transfection reagent FuGENE 6 (Promega, Madison, WI, USA) according to the manufacturer's protocol. After 30 to $40 \mathrm{~h}$, the cells were trypsinized and used for whole-cell recording.

\section{Molecular biology}

Plasmid containing human TRPC5 gene was given kindly by Dr. Shuji Kaneko in Japan. Point mutations in TRPC5 were introduced using the QuickChange site-directed mutagenesis kit (Agilent Technologies, Santa Clara, CA, USA) and appropriate primer sets. Sequences of the mutants were confirmed by DNA sequencing.

\section{Electrophysiology}

The whole-cell patch clamp was performed to measure the TRPC channel current in HEK cells. The transfected cells were trypsinized from the culture well and attached to coverslips in the small chamber on an inverted microscope for $10 \mathrm{~min}$ prior to patch recording. The currents were recorded using an Axopatch 200B patch clamp amplifier (Molecular Devices, San Jose, CA, USA). The bath solutions were constantly perfused with normal Tyrode (NT) solution at a rate of 1 to $2 \mathrm{ml} / \mathrm{min}$. Glass microelectrodes with 2 to $4 \mathrm{M} \Omega$ resistance when filled with internal solution were used to obtain gigaohm seals. For some experiments, after establishing the whole-cell configuration, the external solution was changed from NT to $\mathrm{Cs}^{+}$-rich solution for recording TRPC5 current in HEK293 cells. The extracellular ion composition was altered to examine the activity of TRPC5 channel, especially for cations with high permeability. Voltage ramp pulse was applied from +100 to $-100 \mathrm{mV}$ for $500 \mathrm{msec}$ at $-60-\mathrm{mV}$ holding potential at every $20 \mathrm{sec}$. Experiments were performed at room temperature $\left(20^{\circ} \mathrm{C}-24^{\circ} \mathrm{C}\right)$. The pCLAMP (version 10.2) and Digidata 1440A (Axon Instruments) software programs were used for data acquisition and the application of command pulses. The data were filtered at $5 \mathrm{kHz}$ and displayed on a computer monitor. The data were analyzed using pCLAMP (version 10.2) and OriginPro 8 (OriginLab, Northampton, MA, USA).

\section{Western blotting}

Cells were plated in 6-well dishes. Lysates were prepared in lysis buffer (0.5\% Triton X-100, $150 \mathrm{mM} \mathrm{NaCl}, 50 \mathrm{mM}$ HEPES, $2 \mathrm{mM}$ $\mathrm{MgCl}_{2}, 2 \mathrm{mM}$ ethylenediaminetetraacetic acid [EDTA], $\mathrm{pH} 7.4$ ) via passage 15 to 20 times through a 26 -gauge needle. After lysates were centrifuged at $13,000 \times g$ for $10 \mathrm{~min}$ at $4^{\circ} \mathrm{C}$, the protein concentration in the supernatants was determined. The extracted proteins were separated on sodium dodecyl sulfate-polyacrylamide gel electrophoresis (SDS-PAGE) and transferred to nitrocellulose membranes. The following primary antibodies were used for Western analysis: rabbit antibody against GFP (A-11122; Invitrogen, Carlsbad, CA, USA) and mouse antibody against $\beta$-tubulin (T-4026; Sigma Aldrich, St. Louis, MO, USA). Image-J Software was used to quantify the level of protein expression.

\section{Western blotting and surface biotinylation}

Cells were plated in 6-well dishes. Lysates were prepared in lysis buffer (0.5\% Triton X-100, $150 \mathrm{mM} \mathrm{NaCl}, 50 \mathrm{mM}$ HEPES, $2 \mathrm{mM}$ $\mathrm{MgCl}_{2}, 2 \mathrm{mM}$ EDTA, $\mathrm{pH} 7.4$ ) via passage 15 to 20 times through a 26-gauge needle. After lysates were centrifuged at 13,000 $\times \mathrm{g}$ for $10 \mathrm{~min}$ at $4^{\circ} \mathrm{C}$, the protein concentration in the supernatants was determined. The extracted proteins were separated on SDS-PAGE and transferred to nitrocellulose membranes. The following primary antibodies were used for Western analysis: rabbit antibody against GFP (A11122; Life Technologies) and mouse antibody against $\beta$-tubulin (T-4026; Sigma Aldrich). Image-J Software was used to quantify the level of protein expression.

For surface biotinylation, HEK293 cells were transfected with wild-type (WT) TRPC5 or mutants. After $24 \mathrm{~h}$, cell membrane protein biotinylation was performed. Cells were washed in phosphate-buffered saline (PBS) and then incubated with $0.5 \mathrm{mg} / \mathrm{ml}$ Sulfo-NHS-LC-Biotin in PBS on ice for $30 \mathrm{~min}$. Free biotin was quenched by $100 \mathrm{mM}$ glycine in PBS, followed by lysing procedure at $4^{\circ} \mathrm{C}$ for $30 \mathrm{~min}$. Lysates were centrifuged at $13,000 \times \mathrm{g}$ for $10 \mathrm{~min}$ at $4^{\circ} \mathrm{C}$, and protein concentration in the supernatants was determined. A $50 \%$ of Pierce ${ }^{\mathrm{TM}}$ Avidin beads (Thermo Scientific, 
A

$$
\text { TRPC5 }
$$

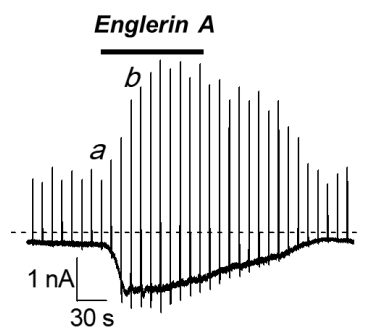

B

K554N

Englerin $A$
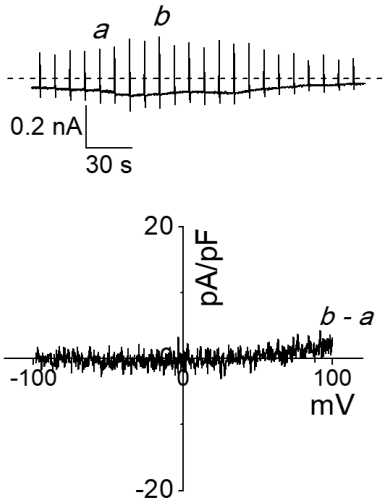

D

\section{$E 598 Q$}

H594N

Englerin A

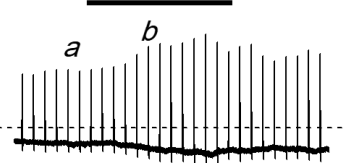

$0.2 \mathrm{nA}$

$30 \mathrm{~s}$

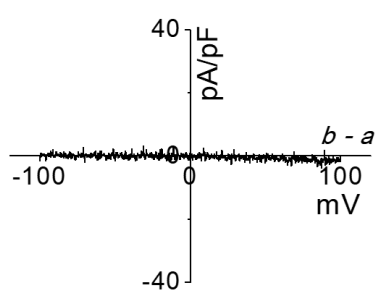

$-40$

$\mathrm{E}$

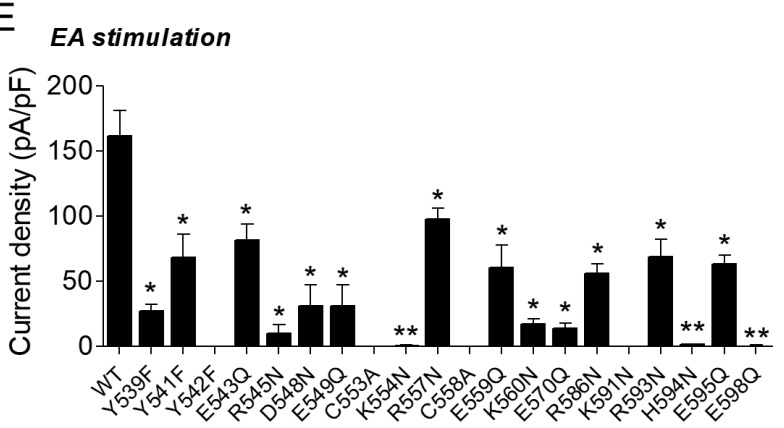

Fig. 1. Englerin A (EA)-induced currents were abolished in TRPC $5^{\mathrm{K} 554 \mathrm{~N}}, \mathrm{TRPC}^{\mathrm{H} 594 \mathrm{~N}}$, and TRPC5 $5^{\mathrm{E} 598 \mathrm{O}}$. (A) A representative full current trace of TRP$\mathrm{C} 5^{\mathrm{WT}}$ induced by $100 \mathrm{nM}$ of EA (top) and the current (I)-voltage (V) relationship of current increases ( $b$-a) by EA (bottom). The $a, b$ indicate the basal current $(a)$ and the EA-induced peak current $(b)$. The currents were recorded in TRPC5-expressing HEK293 cells using the whole-cell patch clamp technique. At a holding potential of $-60 \mathrm{mV}$, the ramp pulse was applied from $100 \mathrm{mV}$ to $-100 \mathrm{mV}$ at every 20 sec. (B) A representative full current trace of TRPC ${ }^{\mathrm{K} 554 \mathrm{~N}}$ induced by EA (top) and the I-V relationship of current increases by EA (bottom). (C) A representative full current trace of TRPC $5^{\mathrm{H} 594 \mathrm{~N}}$ induced by EA (top) and the I-V relationship of current increases by EA (bottom). (D) A representative full current trace of TRPC5 ${ }^{\mathrm{E} 980}$ induced by EA (top) and the I-V relationship of current changes by EA (bottom). (E) A summarized current density at $-60 \mathrm{mV}$ of TRPC $5^{\mathrm{WT}}$ and mutants stimulated by EA (100 nM). TRPC5, transient receptor potential canonical 5; WT, wild type; HEK, human embryonic kidney. ${ }^{*} \mathrm{p}<0.05$ and ${ }^{* *} \mathrm{p}<0.01$. The dotted gray lines in (AD) indicate baseline. 
Waltham, MA, USA) was added to cell lysates. After incubation for $1 \mathrm{~h}$ at room temperature, beads with protein were washed 3 times with $0.5 \%$ Triton X-100 in PBS, and proteins were extracted in sample buffer. Collected proteins were then analyzed by Western blot.

\section{Solutions and drugs}

For recordings of the TRPC channels, we used NT solution and $\mathrm{Cs}^{+}$-rich solution. The NT solution contained $135 \mathrm{mM} \mathrm{NaCl}, 5$ $\mathrm{mM} \mathrm{KCl}, 2 \mathrm{mM} \mathrm{CaCl}_{2}, 1 \mathrm{mM} \mathrm{MgCl}_{2}, 10 \mathrm{mM}$ glucose, and $10 \mathrm{mM}$ HEPES with $\mathrm{pH}$ of 7.4 adjusted with $\mathrm{NaOH}$. The $\mathrm{Cs}^{+}$-rich external solution contained equimolar $\mathrm{CsCl}$ instead of $\mathrm{NaCl}$ and $\mathrm{KCl}$ with

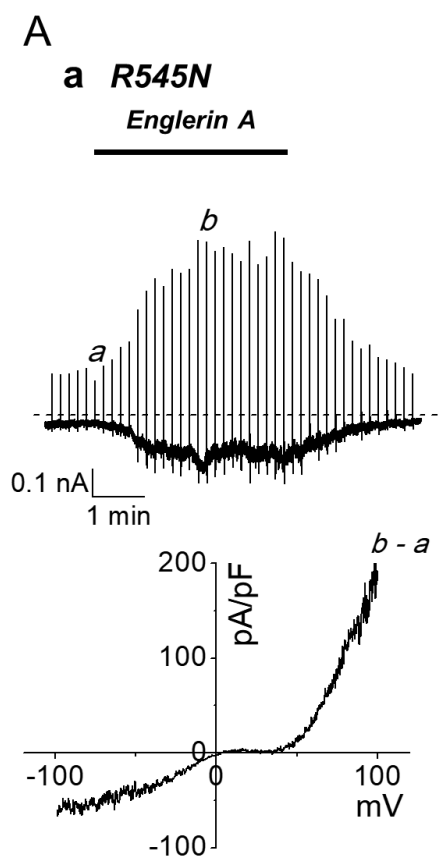

$B$
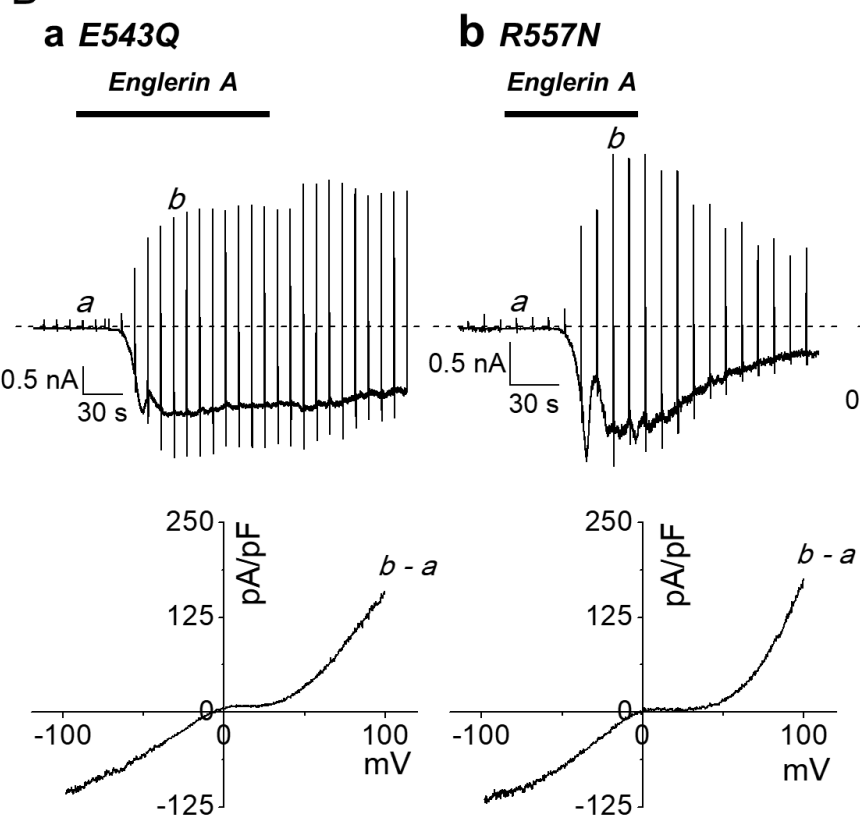

b E549Q

Englerin $A$
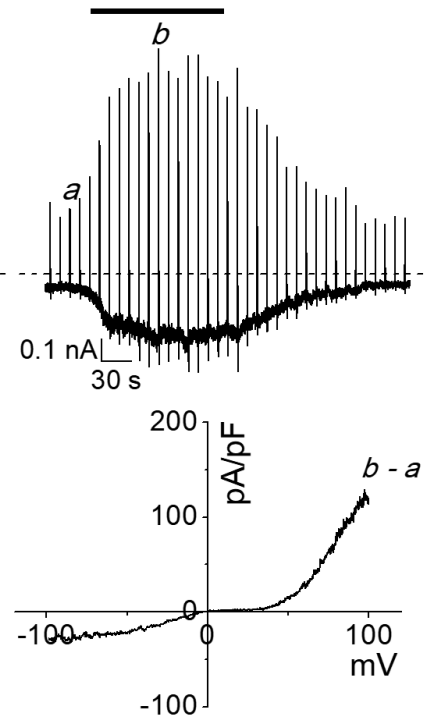

$\mathrm{mV}$

C K560N

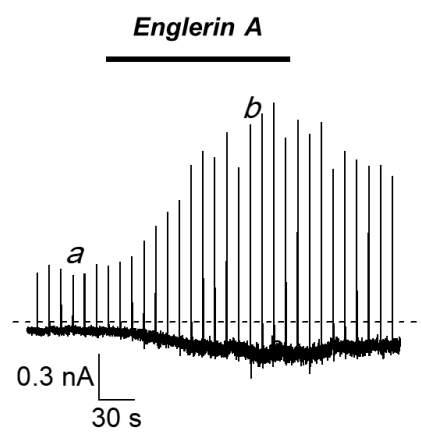

d E570Q
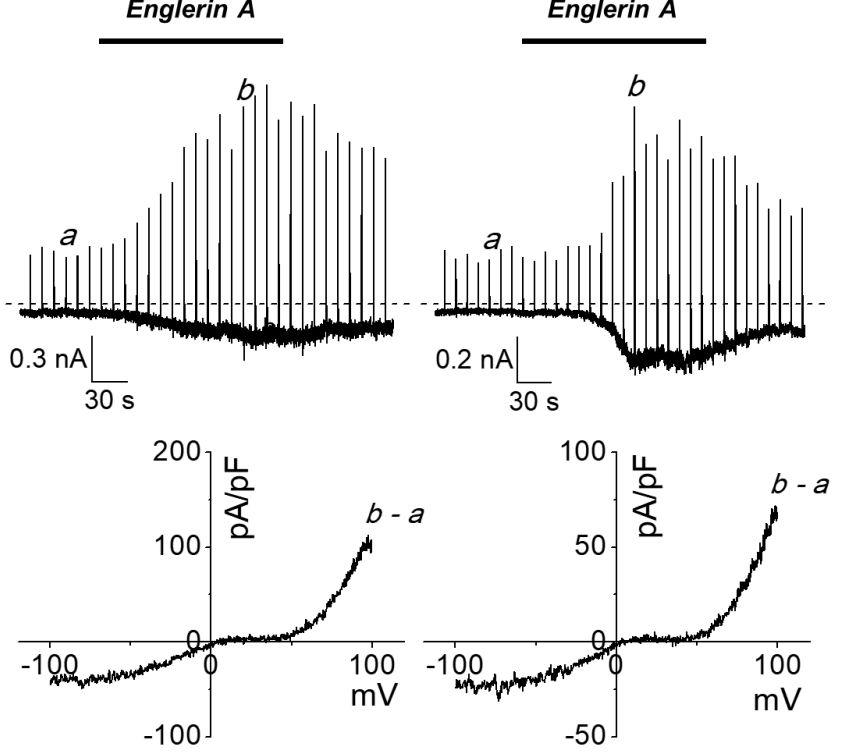

C R593N

d $E 595 Q$

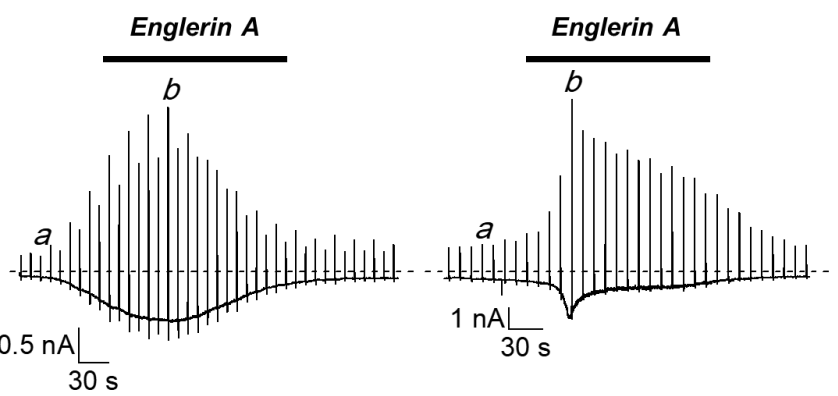

Fig. 2. Effects of englerin A on TRPC5 mutants. (A) A representative full current trace (top) and the I-V relationship of current increases (b-a) by EA (bottom) of $\operatorname{TRPC}^{\mathrm{R} 545 \mathrm{~N}}(\mathrm{~A}-\mathrm{a}), \operatorname{TRPC}^{\mathrm{E} 5490}(\mathrm{~A}-\mathrm{b}), \operatorname{TRPC}^{\mathrm{K} 560 \mathrm{~N}}(\mathrm{~A}-\mathrm{c})$, and $\operatorname{TRPC}^{\mathrm{E5} 70 \mathrm{O}}(\mathrm{A}-\mathrm{d})$. (B) A representative full current trace (top) and the I-V relationship of current increases by EA (bottom) of TRPC5 ${ }^{\mathrm{E} 433 \mathrm{O}}(\mathrm{B}-\mathrm{a}), \operatorname{TRPC}^{\mathrm{R} 557 \mathrm{~N}}(\mathrm{~B}-\mathrm{b}), \operatorname{TRPC}^{\mathrm{R} 593 \mathrm{~N}}(\mathrm{~B}-\mathrm{c})$, and TRPC5 ${ }^{\mathrm{E} 595 \mathrm{O}}(\mathrm{B}-\mathrm{d})$. The dotted gray line indicates baseline. The $a, b$ indicate the basal current ( $a$ ) and the EA-induced peak current (b). TRPC5, transient receptor potential canonical 5. 
$\mathrm{pH}$ adjusted to 7.4 using $\mathrm{CsOH}$. The internal solution contained $140 \mathrm{mM} \mathrm{CsCl}, 10 \mathrm{mM}$ HEPES, $0.2 \mathrm{mM}$ Tris-GTP (Tris-guanosine 5-triphosphate), $0.5 \mathrm{mM}$ EGTA, and $3 \mathrm{mM} \mathrm{Mg-ATP}$ (adenosine 5 -triphosphate) with $\mathrm{pH}$ of 7.3 adjusted with $\mathrm{CsOH}$ and used 0.2 mM GTP $\gamma$ (guanosine 5'-triphosphate- $\gamma$ ). All reagents were purchased from Sigma Aldrich).

\section{Statistics}

All statistical analysis was done with GraphPad Prism 5 (GraphPad Software Inc., San Diego, CA, USA). Results are presented as means \pm standard error of mean. Statistical data were obtained by paired or unpaired Student's t-test and ANOVA. The $\mathrm{p}$ values less than 0.05 were considered statistically significant. The number of whole cell recordings is indicated by $n$.

\section{RESULTS}

\section{Identification of putative EA-interaction sites in TRPC5 ion channel}

To investigate on the mechanism of TRPC5 ion channel activation by EA, we first generated TRPC5 mutants in which selected amino acids within the pore region are mutated. The mutants were generated according to their propensity to sense $\mathrm{H}^{+}$or $\mathrm{OH}^{-}$ ions. The current was recorded under the condition of $150 \mathrm{mM}$ of external $\mathrm{Na}^{+}$and without GTP $\gamma \mathrm{S}$ in the patch pipette, which is an activator of TRPC5. Each mutant was over-expressed in HEK293 cells and its whole-cell currents were recorded under the same condition. When $100 \mathrm{nM}$ of EA was applied, the current change $(b-a)$ of TRPC ${ }^{\mathrm{WT}}$ was $-161.63 \pm 19.50 \mathrm{pA} / \mathrm{pF}(\mathrm{n}=6)$ at $-60 \mathrm{mV}$ (Fig. 1A, E). As shown in Fig. 1E, the mutants showed their varying responses to EA, and their response patterns could be divided into three categories (Fig. 1E). First, there was no current response to EA in six mutants: $\mathrm{TRPC}^{\mathrm{Y} 542 \mathrm{~F}}, \mathrm{TRPC} 5^{\mathrm{C} 553 \mathrm{~A}}$, $\mathrm{TRPC}^{\mathrm{K} 554 \mathrm{~N}}, \mathrm{TRPC}^{\mathrm{C} 558 \mathrm{~A}}, \mathrm{TRPC}^{\mathrm{H} 594 \mathrm{~N}}$, and TRPC5 ${ }^{\mathrm{E} 598 \mathrm{Q}}$. We previously reported that we could not observe whole-cell TRPC5 currents in TRPC5 $5^{\mathrm{Y} 542 \mathrm{~F}}$, TRPC $5^{\mathrm{C} 553 \mathrm{~A}}$, and TRPC $5^{\mathrm{C} 558 \mathrm{~A}}$ overexpressed in HEK293 cells [13]. Western blot analysis also showed remarkably reduced expression of total TRPC $5^{\mathrm{Y} 542 \mathrm{~F}}$ protein and expressed protein at the plasma membrane (Supplementary Fig. 1), and TRPC $5{ }^{\mathrm{C} 553 \mathrm{~A}}$ and TRPC $5^{\mathrm{C} 558 \mathrm{~A}}$ protein at the plasma membrane [2]. The mutants TRPC5 $5^{\mathrm{K} 554 \mathrm{~N}}$ (Fig. 1B), TRPC5 ${ }^{\mathrm{H} 594 \mathrm{~N}}$ (Fig. 1C), and TRPC5 $^{\mathrm{E} 598 \mathrm{Q}}$ (Fig. 1D) were expressed in HEK293 cells. Compared to WT, the mutant H594N and E598Q showed similar total protein and expressed protein in the plasma membrane whereas K554N was decreased at both total and expressed protein at the plasma membrane (Supplementary Fig. 1). Their EA-induced currents, however, were increased only to $-0.30 \pm 0.42 \mathrm{pA} / \mathrm{pF}$ ( $\mathrm{n}=$ 5), $-1.42 \pm 0.35 \mathrm{pA} / \mathrm{pF}(\mathrm{n}=5),-0.10 \pm 0.63 \mathrm{pA} / \mathrm{pF}(\mathrm{n}=5)$, respectively. The positive effect of EA on TRPC5 was abolished in these three mutants. The mutants in the second group showed that the current changes in the middle range from -10 to $-30 \mathrm{pA} / \mathrm{pF}$. The EA-induced currents were not abolished, but reduced (Fig. 1E). The mutant TRPC $5^{(\mathrm{R} 545 \mathrm{~N})}$ showed relatively substantial reduction in EA-induced current increases, yielding $-10.08 \pm 6.17 \mathrm{pA} / \mathrm{pF}$ (n $=5$ ) (panel a in Fig. 2A). Likewise, TRPC5 ${ }^{\mathrm{Y} 339 \mathrm{~F}}(-27.26 \pm 5.04 \mathrm{pA} /$ $\mathrm{pF}[\mathrm{n}=5]), \mathrm{TRPC}^{\mathrm{D} 548 \mathrm{~N}}(-28.14 \pm 8.31 \mathrm{pA} / \mathrm{pF}[\mathrm{n}=5]), \mathrm{TRPC}^{\mathrm{E} 549 \mathrm{Q}}$ $(-30.80 \pm 16.25 \mathrm{pA} / \mathrm{pF}[\mathrm{n}=5]$; panel b in Fig. $2 \mathrm{~A}), \mathrm{TRPC}^{\mathrm{K} 560 \mathrm{~N}}$ $(-17.24 \pm 3.64 \mathrm{pA} / \mathrm{pF}[\mathrm{n}=5]$; panel $\mathrm{c}$ in Fig. $2 \mathrm{~A})$, and TRPC5 ${ }^{\mathrm{E570Q}}$ $(-13.69 \pm 3.97 \mathrm{pA} / \mathrm{pF}[\mathrm{n}=5]$; panel d in Fig. $2 \mathrm{~A})$ showed similar reductions in EA-induced current increases. Unlike the mutants

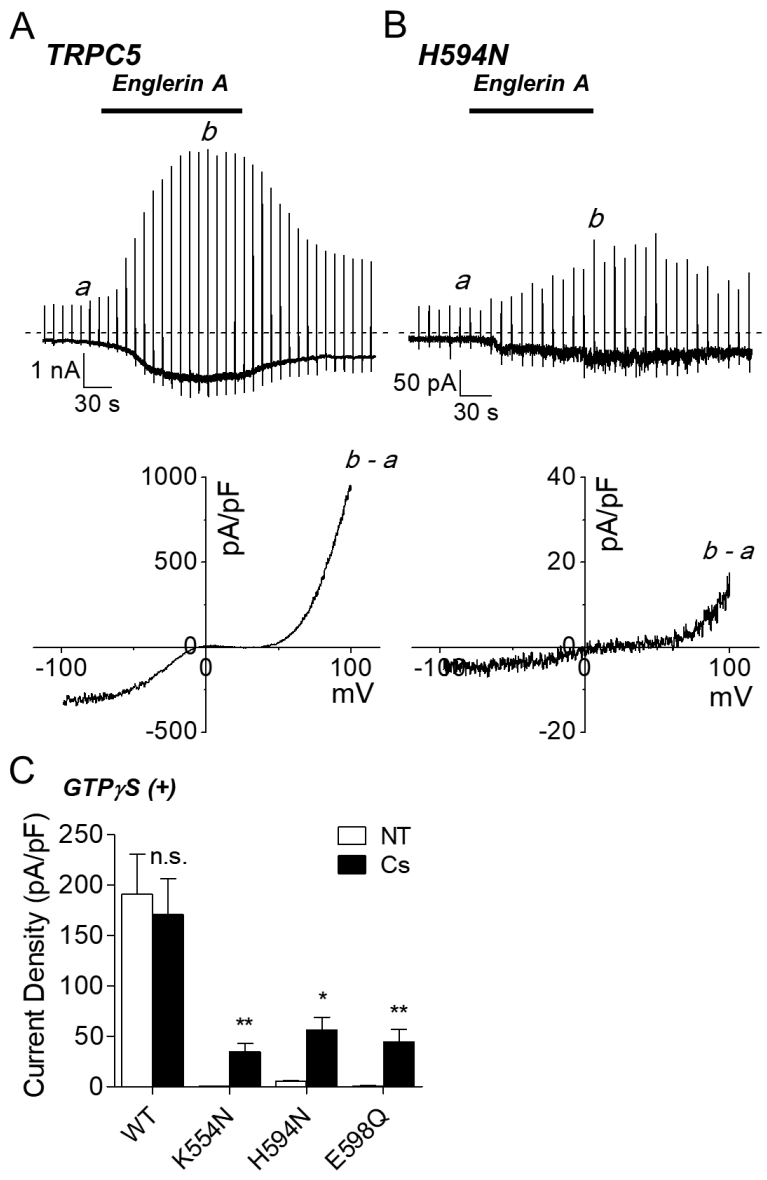

Fig. 3. Effects of englerin $A(E A)$ on GTP $\gamma$ S-induced current increases of TRPC ${ }^{\mathrm{WT}}$ and TRPC5 mutants. (A) A representative full current trace of TRPC5 ${ }^{\mathrm{WT}}$ induced by intracellular GTP $\mathrm{S}$ and EA (top) and the I-V relationship of current increases $(b-a)$ by EA (bottom). The $a, b$ indicates the basal current (a) and the peak current (b). (B) A representative full current trace of TRPC $5^{\mathrm{H} 594 \mathrm{~N}}$ induced by intracellular GTP $\gamma$ S and EA (top) and the I-V relationship of current increases by EA (bottom). (C) A summarized current density at $-60 \mathrm{mV}$ of TRPC ${ }^{\mathrm{WT}}$, TRPC $5^{\mathrm{K} 55 \mathrm{AN}}$, TRPC $5^{\mathrm{H} 594 \mathrm{~N}}$, and TRPC $5^{\mathrm{E5980}}$ induced by intracellular GTP $\gamma \mathrm{S}$ and EA under the condition of $\mathrm{Na}$ (open column) and under the condition of $\mathrm{Cs}^{+}$(filled column). TRPC5, transient receptor potential canonical 5; WT, wild type; GTP $\gamma$, guanosine 5'-O-[gamma-thio]triphosphate. ${ }^{*} \mathrm{p}<0.05$ and ${ }^{* *} \mathrm{p}<$ 0.001 . The dotted gray line in $A$ and $B$ indicates baseline. 
A
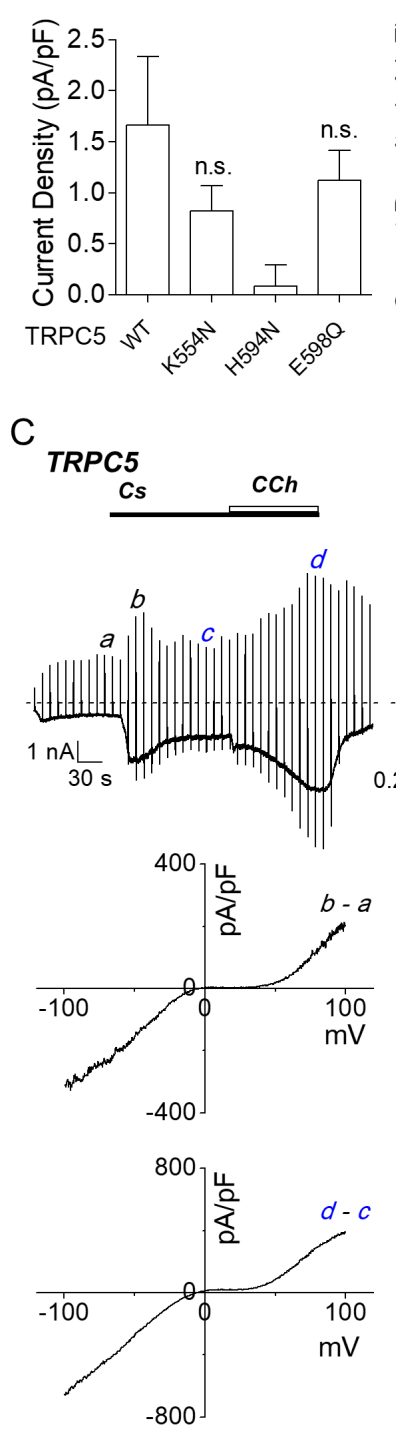

D

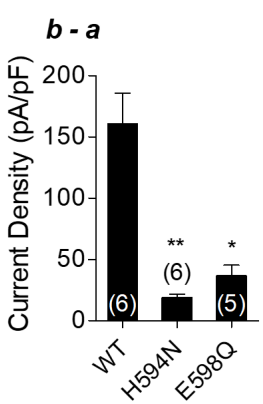

$\mathrm{B}$

E

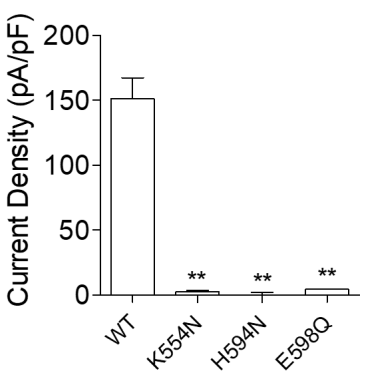

H594N

Cs

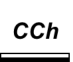

E598Q

Cs cCh
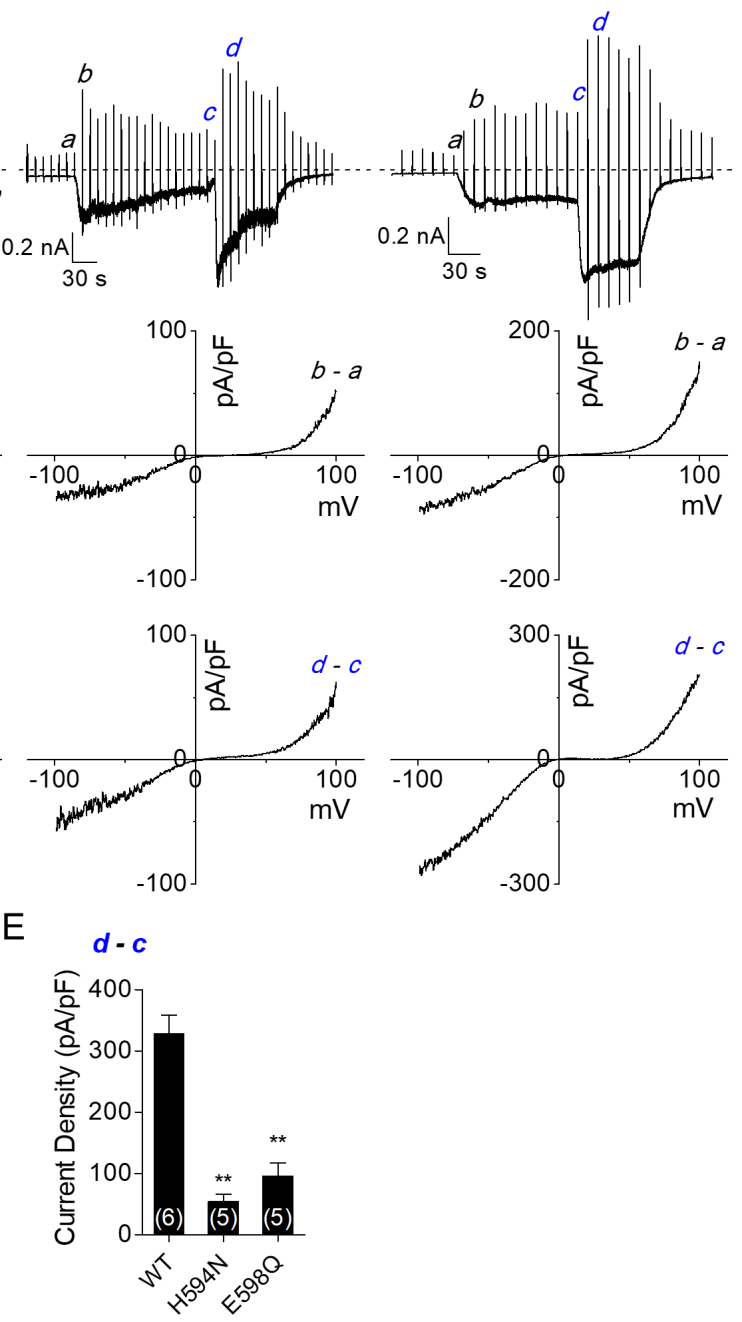

Fig. 4. Effects of carbachol (CCh) on TRPC5 ${ }^{\mathrm{WT}}$ and TRPC5 mutants. (A) A summarized current density at $-60 \mathrm{mV}$ of TRPC5 $5^{\mathrm{WT}}$ and the mutants with CCh stimulation under condition of $\mathrm{Na}$. (B) A summarized current density at $-60 \mathrm{mV}$ of TRPC5 ${ }^{\mathrm{WT}}$ and the mutants with $\mathrm{CCh}$ stimulation under condition of Na in HEK cells expressing human M3 muscarinic receptor. (C) A representative full current trace of TRPC5 ${ }^{\mathrm{WT}}$, TRPC5 ${ }^{\mathrm{H} 594 \mathrm{~N}}$, and TRPC5 $5^{\mathrm{E} 980}$ induced by CCh (top) and the I-V relationship of current increases by CCh (bottom). After establishing the whole-cell configuration, the external solution was changed from NT to Cs ${ }^{+}$-rich solution for recording TRPC5 current in HEK293 cells. The $a, b, c, d$ indicates the basal current (a) and the peak current (b) under the condition of $\mathrm{Cs}^{+}$, and the basal current (c) and the peak current $(d)$ under the condition of $\mathrm{Cs}^{+}$and $\mathrm{CCh}$. The I-V relationship of current increases by $C_{s}(b-a)$ was obtained by subtracting a from $b$ and the I-V relationship of current increases by $C C h(d-c)$ by subtracting $c$ from $d$. (D) A summarized current density at $-60 \mathrm{mV}$ of TRPC5 ${ }^{\mathrm{WT}}$ and the mutants with Cs${ }^{+}$. (E) A summarized current density at $-60 \mathrm{mV}$ of TRPC $5^{\mathrm{WT}}$ and the mutants with CCh. TRPC5, transient receptor potential canonical 5; WT, wild type; n.s., not significant; HEK, human embryonic kidney. ${ }^{*} \mathrm{p}<0.05$ and ${ }^{* *} \mathrm{p}<0.01$. The dotted gray line indicates baseline. 
in the second group, the EA-induced current increases of the third group, which are TRPC $5^{\mathrm{Y} 441 \mathrm{~F}}(-68.25 \pm 17.65 \mathrm{pA} / \mathrm{pF}[\mathrm{n}=$ 5]), $\operatorname{TRPC5}^{\mathrm{E} 43 \mathrm{Q}}(-81.45 \pm 12.43 \mathrm{pA} / \mathrm{pF}$ [n = 5]; panel a in Fig. 2B), $\mathrm{TRPC}^{\mathrm{R} 557 \mathrm{~N}}(-97.60 \pm 8.21 \mathrm{pA} / \mathrm{pF}[\mathrm{n}=5]$; panel b in Fig. 2B), TRP$\mathrm{C}^{\mathrm{E} 559 \mathrm{Q}}(-60.19 \pm 17.64 \mathrm{pA} / \mathrm{pF}[\mathrm{n}=5]), \mathrm{TRPC}^{\mathrm{Y} 586 \mathrm{~F}}(-81.45 \pm 12.43$ $\mathrm{pA} / \mathrm{pF}[\mathrm{n}=5]), \mathrm{TRPC}^{\mathrm{R} 593 \mathrm{~N}}(-68.86 \pm 13.28 \mathrm{pA} / \mathrm{pF}[\mathrm{n}=5]$; panel c in Fig. 2B), and TRPC $5^{\mathrm{E} 595 \mathrm{Q}}(-62.98 \pm 6.87 \mathrm{pA} / \mathrm{pF}[\mathrm{n}=5]$; panel $\mathrm{d}$ in Fig. $2 \mathrm{~B}$ ) were reduced to greater amplitudes. These results suggest that the three specific residues, Lys-554, His-594, and Glu598, are putative EA interaction sites in the TRPC5 ion channel. On the other hand, it is difficult to rule out the possibility that EA has no effect on the three mutants because there are permeability changes or modulation of gating due to mutation.

\section{Functional intactness of TRPC5 pore mutants}

To examine whether TRPC5 ${ }^{\mathrm{K} 554 \mathrm{~N}}$, TRPC5 ${ }^{\mathrm{H} 594 \mathrm{~N}}$, and TRPC5 $5^{\mathrm{E} 598 \mathrm{Q}}$ mutants are functionally intact, we used GTP $\gamma$ S-included internal solution, while other conditions were maintained. Application of EA on the TRPC $5{ }^{\mathrm{WT}}$-expressing HEK293 cell increased the current by $-190.67 \pm 39.88 \mathrm{pA} / \mathrm{pF}(\mathrm{n}=6)($ Fig. $3 \mathrm{~A}, \mathrm{C})$. The EA-induced current increases of TRPC $5^{\mathrm{K} 554 \mathrm{~N}}, \mathrm{TRPC}^{\mathrm{H} 594 \mathrm{~N}}$, and TRPC $5^{\mathrm{E} 598 \mathrm{Q}}$ were $-0.32 \pm 0.39 \mathrm{pA} / \mathrm{pF}(\mathrm{n}=5),-5.47 \pm 0.61 \mathrm{pA} / \mathrm{pF}$ $(\mathrm{n}=5)$, and $-0.55 \pm 0.51 \mathrm{pA} / \mathrm{pF}(\mathrm{n}=5)$, respectively (Fig. $3 \mathrm{~B}, \mathrm{C})$. Compared to TRPC5 ${ }^{\mathrm{WT}}$, the three mutants lost channel activation by EA even with GTP $\gamma$ S, which is a TRPC5 activator (Fig. 3C).

Since TRPC5 has higher permeability to $\mathrm{Cs}^{+}$, we used $\mathrm{Cs}^{+}$-rich external solution in addition to GTP $\gamma \mathrm{S}$ in the internal solution. The EA-induced current increases of TRPC $5^{\mathrm{WT}}$ was $-170.61 \pm$ $35.35 \mathrm{pA} / \mathrm{pF}(\mathrm{n}=6)$. With $\mathrm{Cs}^{+}$-rich solution, the current increase of the three mutants were restored, although one-fourth of WT. Each mutant, TRPC5 $5^{\mathrm{K} 554 \mathrm{~N}}, \mathrm{TRPC} 5^{\mathrm{H} 594 \mathrm{~N}}$, and $\mathrm{TRPC} 5^{\mathrm{E} 598 \mathrm{Q}}$ showed current increases by $-34.66 \pm 8.42 \mathrm{pA} / \mathrm{pF}(\mathrm{n}=5),-55.96 \pm 12.96$ $\mathrm{pA} / \mathrm{pF}(\mathrm{n}=5)$, and $-44.64 \pm 12.50 \mathrm{pA} / \mathrm{pF}(\mathrm{n}=5)$, respectively (Fig. 3C, Supplementary Fig. 1). These results suggest that three mutants did not lose channel function completely.

Since muscarinic stimulation activates TRPC5, we applied CCh without any expression of muscarinic receptor prior to coexpression with the receptor. Whole-cell currents from each mutant showed the typical double rectifying I/V curve although the amplitude was less than $2 \mathrm{pA} / \mathrm{pF}$ (Fig. 4A) except for TRPC5 ${ }^{\mathrm{H} 594 \mathrm{~N}}$. Next, we co-expressed M3 muscarinic receptor with each mutant and applied CCh to activate TRPC5 channels (Fig. 4B). Wholecell currents from each mutant showed the typical double rectifying I/V curve except for TRPC $5^{\mathrm{H} 594 \mathrm{~N}}$. Finally, CCh was applied under the condition of $140 \mathrm{mM}$ of external $\mathrm{Cs}^{+}$to increase the TRPC5 currents. Since TRPC5 has higher permeability to $\mathrm{Cs}^{+}$, changing NT to Cs solution increased TRPC5 currents. CCh application further increased TRPC5 current. $\mathrm{Cs}^{+}$-induced basal current (Fig. 4C) and CCh-induced current (Fig. 4D) at each mutant were smaller than that of WT TRPC5. These results suggest that each mutant has an electrophysiological function, although
A

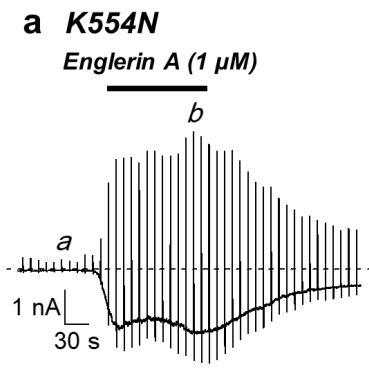

b $H 594 N$ Englerin A (1 $\mu M)$

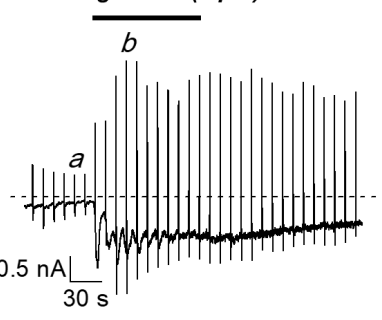

$E 598 Q$ Englerin A (1 $\mu \mathrm{M})$

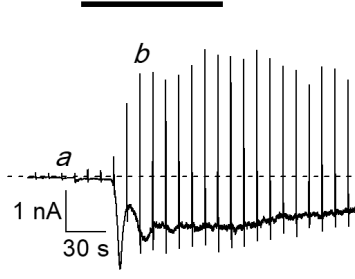

B

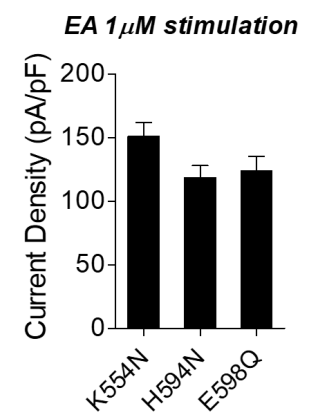

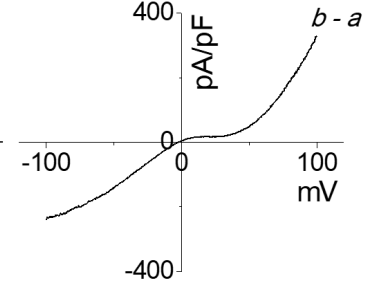

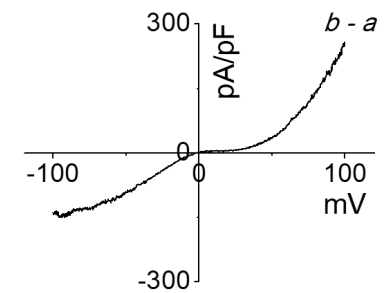

$-300$

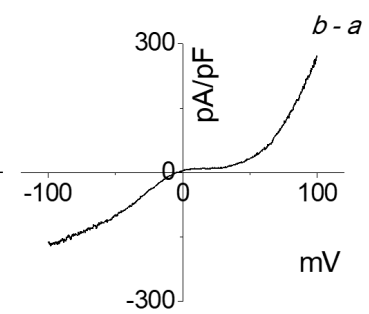

$-300$

$\mathrm{mV}$

$-a$
Fig. 5. Effects of $1 \mu \mathrm{M}$ of englerin A (EA) on TRPC5 ${ }^{\mathrm{WT}}$ and TRPC5 mutants. (A) A representative full current trace (left panel) and the I-V relationship of current increases (b-a) by EA (right panel) of TRPC5 $5^{\mathrm{K} 554 \mathrm{~N}}$ $(A-a), \operatorname{TRPC}^{\mathrm{H} 594 \mathrm{~N}}(\mathrm{~A}-\mathrm{b})$, and TRPC5 ${ }^{\mathrm{E} 598 \mathrm{O}}(\mathrm{A}-\mathrm{c})$. The $a, b$ indicates the basal current (a) and the EA-induced peak current (b). (B) A summarized current density at $-60 \mathrm{mV}$ of TRPC $5^{\mathrm{WT}}$ and the mutants with EA. The dotted gray line indicates baseline. TRPC5, transient receptor potential canonical 5; WT, wild type.

the mutation affected the pore region and decreased the level of their response to TRPC5 agonists. 


\section{Activation of TRPC5 pore mutant E595Q/E598Q}

Since TRPC5 E595Q/E598Q revealed a significant receptoractivated current [14], we generated E595Q/E598Q double mutant and tested the effect of CCh instead of histamine. Without M3 receptor expression, CCh induced similar currents in E595Q/ E598Q double mutant compared with WT (Supplementary Fig. 2). $\mathrm{Cs}^{+}$-induced basal current was smaller in E595Q/E598Q double mutant (Supplementary Fig. 2B). Under the condition of $\mathrm{Cs}^{+}$, CCh also induced smaller currents compared with WT (Supplementary Fig. 2C). We investigated whether E595Q/E598Q double mutant responds to EA (Supplementary Fig. 3). E595Q/E598Q double mutant has a similar response to EA as WT (Supplementary Fig. 3). The I/V curve showed the typical double rectifying shape (panel b in Supplementary Fig. 3A). These results suggest that the response to EA might be different from the response to other agonists, such as $\mathrm{Cs}^{+}$or muscarinic agonists. In addition, the permeability change does not explain the response of three mutants to EA.

\section{Activation of TRPC5 pore mutants by higher concentration of EA}

Since the response to EA might be different from the response to other agonists, such as $\mathrm{Cs}^{+}$or muscarinic agonists, we tested whether the sensitivity to EA changed due to mutations. When 1 $\mu \mathrm{M}$ EA was applied to HEK293 cells expressing WT TRPC5, the cells did not survive such concentrated treatment. When $1 \mu \mathrm{M}$ of EA was applied to HEK cells expressing mutant TRPC5, however, the current increased, and the current amplitude was similar to that of WT TRPC5 stimulated by $100 \mathrm{nM}$ of EA (Fig. 5). These results suggest that the response to EA might be different from the response to other agonists, such as $\mathrm{Cs}^{+}$or muscarinic agonists, and the sensitivity to EA decreased in TRPC $5^{\mathrm{K} 554 \mathrm{~N}}, \mathrm{TRPC}^{\mathrm{H} 594 \mathrm{~N}}$, and TRPC5 $5^{\mathrm{E} 598 \mathrm{Q}}$ mutant, at least ten-fold.

\section{DISCUSSION}

The TRPC5 has been known to be a receptor-activated cationselective and $\left[\mathrm{Ca}^{2+}\right]_{\mathrm{i}}$-dependent channel $[13,15]$. The channel is activated at $100 \mathrm{nM}$ or higher intracellular calcium concentration, but does not depend on the calcium store depletion $[13,15]$. In addition, there is a growing evidence that TRPC 5 channel is also activated by EA. In the present study, we have identified the EA-interaction sites within the pore region of TRPC5, along with other sites that are likely to play an ancillary role in EA-mediated channel regulation. While Lys-554, His-594, and Glu-598 might be likely to be direct interaction sites, Arg-545, Glu-549, Lys-560, Glu-570, Arg-593, and Glu-595 are likely to play indirect roles. When we tested whether the sensitivity to EA changed due to mutations, $1 \mu \mathrm{M}$ of EA increased the current amplitude similar to that of WT TRPC5 stimulated by $100 \mathrm{nM}$ of EA (Fig. 5). The sensitivity to EA decreased in TRPC $5^{\mathrm{K} 554 \mathrm{~N}}, \mathrm{TRPC}^{\mathrm{H} 594 \mathrm{~N}}$, and TRP$\mathrm{C}^{\mathrm{E} 598 \mathrm{Q}}$ mutant at least ten-fold, contrary to our expectation that the response to EA would be completely lost. Thus, we could not rule out that mutations just alter channel conformation. In case of K554N mutant, even though the expression level of total protein is low as in $\mathrm{Y} 542 \mathrm{~F}, \mathrm{Cs}^{+}$induced currents under the condition of GTP $\gamma$ S activator. A similar tendency was obtained in K554R mutant. Further studies are needed to determinew the role of K554 in the TRPC 5 activation of EA using more mutants.

TRPC5 has $65 \%$ sequence identity to TRPC4 but only $45 \%$ sequence identity to TRPC1 $[16,17]$. In this study, we observed that while TRPC5 was activated by EA, cell expressing TRPC1 did not respond to EA (Supplementary Fig. 4). We also showed that TRPC4 was activated by EA [11]. In addition, EA activated TRPC1/4 and TRPC1/5 heteromer and induced cell toxicity via $\mathrm{Na}^{+}$influx instead of $\mathrm{Ca}^{2+}$ influx $[18,19]$. As shown in Supplementary Fig. 4, the three residues in TRPC5 critical for interaction with EA are found different in TRPC1. This provides credible evidence of the different responses of the TRPC1 channel to EA application. The fact that EA activated TRPC1/4 and TRPC1/5 heteromers suggest that activation by EA does not require four protomers of TRPC4 and TRPC5. The recent report uncovers the mechanism of EA-mediated L-type calcium channel activation [12]. EA is reported to have selective binding affinity for dihydropyridine in $\mathrm{Ca}_{\mathrm{v}} 1.2$ channels and modulate calcium signaling in muscle cells and vascular tissue [12]. Although we simply utilized the charged amino acids in the current study, a recent report suggests that EA not only acts upon $\mathrm{OH}^{-}$or $\mathrm{O}$ but also phenyl ring inducing conformational change in L-type calcium channel activation [12]. Three tyrosine mutants, TRPC5 $5^{\mathrm{Y} 539 \mathrm{~F}}$ $\mathrm{TRPC}^{\mathrm{Y541F}}$, and TRPC5 ${ }^{\mathrm{Y} 586 \mathrm{~F}}$, responded to EA to a lesser degree compared with TRPC $5^{\mathrm{WT}}$. To our disappointment, we could not test whether TRPC ${ }^{\mathrm{Y} 542 \mathrm{~F}}$ mutant responds or not because TRP$\mathrm{C}^{\mathrm{Y}}{ }^{\mathrm{Y} 42 \mathrm{~F}}$ mutant did not show the typical double rectifying I/V curve to any agonist, and the expression level of total protein was significantly reduced. Thus, we suggest that tyrosine or phenylalanine is also likely to interact with EA. The present study not only provides the clues for further studies concerning the mechanism of TRP channel regulation, but also building the pore region prediction model, thereby defining the protein structure of TRPC4 and TRPC5.

Recently the structure of mouse TRPC4 [20] and zebrafish TRPC4 [21] was released. There are two gates: the selectivity filter gate and the lower gate at the bundle crossing. The amino acid sequence of the pore region in TRPC5 is highly identical with TRPC4. Using the structure of TRPC4 to predict the location of three amino acids, K554, H594, and E598, we have located K554 between S5 and the pore helix, and H594 between the pore helix and S6 (Supplementary Fig. 4) Interestingly, E598 is located within S6. EA interacting with three amino acids might induce the conformational change in the pore helix and open the selec- 
tivity filter gate formed by N584 and G581. According to structural results of TRPC4, C549, and C554 form a disulfide bridge. We showed that C553 and C558 in TRPC5 as well as C549 and C554 in TRPC4 formed a disulfide bridge [2]. When the disulfide bridge was broken, the TRPC $4 / 5$ channels were translocated to the cytosol. Mutation of C553 (C549 in TRPC4) or C558 (C554 in TRPC4) to alanine or serine in TRPC5, the surface expression of channels was significantly decreased. Whole cell currents were not recorded at C553 or C558 mutants. In TRPC4, E555, located at the end of the pore turret formed a salt bridge with R556 of the adjacent domain. The mutation of K560 (corresponding to R556 of zebrafish TRPC4) to aspargine (N) decreased the EA-induced currents (Fig. 1), whereas the mutation of E559 (corresponding to E555 of TRPC4) to glutamine (Q) decreased the $\mathrm{Cs}^{+}$-induced currents with GTP $\gamma S$ in the internal solution [1].

The E598 residue in TRPC5 is a residue among residues responding to external $\mathrm{La}^{3+}, \mathrm{Gd}^{3+}, \mathrm{Ca}^{2+}$ and $\mathrm{H}^{+}[1,14,22]$. Semtner et al. [22] showed that $\mathrm{H}^{+}$binds with E543 in TRPC5 activated by $\mathrm{G}$ proteins, whereas $\mathrm{H}^{+}$binds with E595 in TRPC5 showing basal spontaneous activity. In the previous report, we suggested that E548, K554, and E598 as well as E543 and E595 are involved in the regulation of TRPC 5 by $\mathrm{H}^{+}$[1]. In addition, we showed that the effect of $\mathrm{La}^{3+}$ as well as $\mathrm{H}^{+}$depended on extracellular cation condition, that is, mainly $\mathrm{Na}^{+}$or $\mathrm{Cs}^{+}$conditions [1]. Jung et al. [14] reported that E543, E595, and E598 are involved in the regulation of TRPC5 by $\mathrm{La}^{3+}$. The double mutation of Glu595/Glu598 in TRPC5 results in an acceleration of $\mathrm{Mn}^{2+}$ influx, an increase in relative $\mathrm{Ca}^{2+}$ permeability, a loss of potentiation by $\mathrm{La}^{3+}$, and a modification of channel inhibition. As Jung et al. [14] suggested, the possible explanation for the increase in the single-channel current of E595Q/E598Q could be due to attenuated block by a physiological cation, and the glutamates (E543, E595, and E598) form a negatively charged ring at the extracellular pore mouth, in tetramers, would act as "gatekeepers," controlling the entry of cations into the pore. Duan et al. [20] showed that E559 also contributes to the negatively charged ring with help of C553C558 disulfide bridge. The effect of E595Q/E598Q mutation on inhibition by $\mathrm{La}^{3+}$, the increase in single-channel current, and the increase in $\mathrm{P}_{\mathrm{Ca}} / \mathrm{P}_{\mathrm{Na}}$ also suggests that this site lies close to, or within, the permeation pathway [14]. Interestingly, E594 (corresponding to E598 of TRPC5) was found to be located within the S6 helix in TRPC4 [20,21] as predicted [14]. In our hands, the response to EA or CCh in E595Q/E598Q mutant was similar to WT TRPC5, although the response of each mutant to EA decreased compared with WT. The degree of response to EA in mutants tends to follow the degree of TRPC 5 activation by any agonist $\left(\mathrm{Cs}^{+}\right.$, GTP $\gamma$ S, CCh). We investigated whether EA caused any permeability change to monovalent cations in WT TRPC 5 or not. The EA-induced current showed the similar aspects for the current amplitude of $\mathrm{Cs}^{+}>\mathrm{Na}^{+}>\mathrm{Li}^{+}$with that in CCh-induced currents (Supplementary Fig. 5). From the shift of the reversal potential at the various monovalent conditions, the sequence of $\mathrm{Px}$ was $\mathrm{P}_{\mathrm{Cs}}$
$>\mathrm{P}_{\mathrm{Na}}>\mathrm{P}_{\mathrm{Li}}$ (Supplementary Fig. 5). The permeability sequence was similar to TRPC4 and TRPC5 activated by GTP $\gamma \mathrm{S}$ or CCh, whereas it was different from that in TRPC1/4 or TRPC1/5 heteromers activated by CCh. In this study, E595Q mutant responded to EA and showed EA-induced current showing typical double rectifying I/V curve, whereas E598Q did not. This result indicates that E598 is more important for EA binding than E595. R593N and E595Q responded to EA transiently (Fig. 2) while H594N did not respond (Fig. 1). Binding of EA to E598 might induce conformation change in the $\mathrm{S} 6$ helix and open the inner gate at the bundle crossing. K554, and H594 locates flanking pore helix, thus binding of both residues with $\mathrm{EA}$ might induce movement of pore helix and open the selectivity filter gate. R593, H594, and E595 seem especially important for EA action to be sustained.

EA activated TRPC1/TRPC5 heteromer with similar potency to TRPC4/5 homomer [9,23]. The sequence of EELQS in TRPC1 is different from HEFTE of TRPC4/5 whereas the sequence CVGIFCEQQ of TRPC1 is similar to CKGIRCEKQ of TRPC4/5 (Supplementary Fig. 4). These results suggest that EA mediates intersubunit interaction from two subunits of TRPC5. In addition, EA might activate TRPC1/5 heteromers by binding with both HEFTE of TRPC4/5 and CVGIFCEQQ of TRPC1 rather than HEFTE of TRPC $4 / 5$ and EELQS of TRPC1.

Rubaiy et al. [24] reported that A54, an EA analog, is a potent antagonist of EA, sharing the same interaction site, at homomeric TRPC5 channels and endogenous TRPC4/TRPC1-containing channels. A54 is also a strong enhancer of TRPC5 and TRPC4 channel activity when induced by $\mathrm{Gd}^{3+}$ and S1P (GPCR agonist), respectively. Rubaiy et al. [24] proposed that the EA and A54 data were explained by the two binding sites in close physical proximity: site 1 for binding without efficacy, and site 2 for binding with efficacy. In their model, EA would bind sites 1 and 2 and therefore, have a direct agonist effect. On the other hand, A54 would bind site 1 in the absence of a cofactor, thereby antagonizing EA and site 2 in the presence of the cofactor impairing the enhancing effect. The fact that cofactor $\mathrm{Gd}^{3+}$ binds to E595/E598 and A54 is a potent enhancer of the channel activity induced by $\mathrm{Gd}^{3+}$ suggests that E595/E598 is a part of the domain allowing A54 to bind with site 2 or site 2 itself. Additionally, it was reported in Chen et al. [25], that a residue, R593, placed in the pore loop close to the TRPC5 extracellular $\mathrm{Gd}^{3+}$ binding site, is critical to confer the sensitivity to GPCR-G $\alpha_{q / 11}$-PLC-dependent gating on TRPC5. GTP $\gamma$ S and GPCR agonists were shown to weakly activate the R593A mutant, while the addition of $\mathrm{Gd}^{3+}$ helped rescue the sensitivity of the mutant to GPCR-G $\alpha_{q / 11}$-PLC-dependent gating. These studies suggest that R593 and E595/E598 can have an important role as a domain that allows the binding of A54 with site 2, or site 2 itself. In our experiments, GTP $\gamma \mathrm{S}$ and EA were shown to moderately activate TRPC5 R593N mutant (Fig. $1 \mathrm{E})$ [1], and such a difference is hypothesized to be due to mutation of R593 to asparagine. Through a computer modelling based on rat TRPV1 structure, Chen et al. [25] showed the critical role 
of Y542, E543, R593, and E959 residues for an establishment of a functional $\mathrm{Gd}^{3+}$ binding site, and the participation of the Y541 residue in fine-tuning $\mathrm{Gd}^{3+}$ sensitivity of the TRPC5 channel. In our experiments, Y542F mutant didn't seem to express well, while Y541F showed moderate responses to EA (Fig. 1E) and GTP $\gamma$ S [1]. In the mTRPC5 structure, revealed by cryogenic electron microscopy (Cryo-EM) [26]. Cryo-EM structure of TRPC5 at $2.8 \AA$ resolution reveals unique and conserved structural elements essential for channel function. As Duan et al. [26] and Li et al. [27] submitted, R593 interacts via a salt bridge with E598 and forms a hydrogen bond with the V590 side chain. These suggest the potential of R593 as the molecular fulcrum that can allow the GPCR-G $\alpha_{\mathrm{q} / 11}$-PLC-powered gating force to efficiently transmit to mTRPC5's pore helix-loop [26,27]. Such results of TRPC4 current activation by EA, but not by GPCR agonist in C549A/C554A double mutant [20] and in human TRPC5 C553S/C558S current (Supplementary Fig. 6), support our hypothesis that the transmission of the GPCR-G $\alpha_{q / 11}$-PLC-powered gating force to TRPC5's pore helix-loop may not be the only gating process. This EA's direct activation may possibly be another pathway to an opening of selectivity filter gate and the inner gate at the bundle crossing.

In conclusion, TRPC5 is activated by $\mathrm{G}$ protein and modulated by lipids, metal ions, and $\mathrm{H}^{+}$[28]. EA interacts with at least three amino acids and induces the conformational changes in the selectivity filter gate and the inner gate at the bundle crossing, therefore opening and activating TRPC5 channel.

\section{ACKNOWLEDGEMENTS}

This study was supported by grants from the National Research Foundation of Korea, which is funded by the Ministry of Science, Information and Communication Technology (ICT), and Future Planning (MSIP) of the Korean government (grant number: 2018R1A4A1023822), KBRI basic research program through Korea Brain Research Institute funded by ministry of Science and ICT (18-BR-03-01) and by the Education and Research Encouragement Fund of Seoul National University Hospital (I.S). S.J., J.Y.K., Y.B., and E.Y.J.P. were supported by the BK21 plus program from the MSIP.

\section{CONFLICTS OF INTEREST}

The authors declare no conflicts of interest.

\section{SUPPLEMENTARY MATERIALS}

Supplementary data including six figures can be found with this article online at http://pdf.medrang.co.kr/paper/pdf/Kjpp/ Kjpp2019-23-03-04-s001.pdf.

\section{REFERENCES}

1. Kim MJ, Jeon JP, Kim HJ, Kim BJ, Lee YM, Choe H, Jeon JH, Kim SJ, So I. Molecular determinant of sensing extracellular $\mathrm{pH}$ in classical transient receptor potential channel 5. Biochem Biophys Res Commun. 2008;365:239-245.

2. Hong C, Kwak M, Myeong J, Ha K, Wie J, Jeon JH, So I. Extracellular disulfide bridges stabilize TRPC5 dimerization, trafficking, and activity. Pflugers Arch. 2015;467:703-712.

3. Jeon JP, Roh SE, Wie J, Kim J, Kim H, Lee KP, Yang D, Jeon JH, Cho $\mathrm{NH}$, Kim IG, Kang DE, Kim HJ, So I. Activation of TRPC4 $\beta$ by $\mathrm{G}_{\alpha_{i}}$ subunit increases $\mathrm{Ca}^{2+}$ selectivity and controls neurite morphogenesis in cultured hippocampal neuron. Cell Calcium. 2013;54:307-319.

4. Venkatachalam K, Zheng F, Gill DL. Regulation of canonical transient receptor potential (TRPC) channel function by diacylglycerol and protein kinase C. J Biol Chem. 2003;278:29031-29040.

5. Sukumar P, Beech DJ. Stimulation of TRPC5 cationic channels by low micromolar concentrations of lead ions $\left(\mathrm{Pb}^{2+}\right)$. Biochem Biophys Res Commun. 2010;393:50-54.

6. Hong C, Seo H, Kwak M, Jeon J, Jang J, Jeong EM, Myeong J, Hwang YJ, Ha K, Kang MJ, Lee KP, Yi EC, Kim IG, Jeon JH, Ryu H, So I. Increased TRPC5 glutathionylation contributes to striatal neuron loss in Huntington's disease. Brain. 2015;138:3030-3047.

7. Yoshida T, Inoue R, Morii T, Takahashi N, Yamamoto S, Hara Y, Tominaga M, Shimizu S, Sato Y, Mori Y. Nitric oxide activates TRP channels by cysteine S-nitrosylation. Nat Chem Biol. 2006;2:596607.

8. Zhu MH, Chae M, Kim HJ, Lee YM, Kim MJ, Jin NG, Yang DK, So I, Kim KW. Desensitization of canonical transient receptor potential channel 5 by protein kinase C. Am J Physiol Cell Physiol. 2005;289:C591-C600.

9. Akbulut Y, Gaunt HJ, Muraki K, Ludlow MJ, Amer MS, Bruns A, Vasudev NS, Radtke L, Willot M, Hahn S, Seitz T, Ziegler S, Christmann M, Beech DJ, Waldmann H. (-)-Englerin A is a potent and selective activator of TRPC4 and TRPC5 calcium channels. Angew Chem Int Ed Engl. 2015;54:3787-3791.

10. Beck A, Speicher T, Stoerger C, Sell T, Dettmer V, Jusoh SA, Abdulmughni A, Cavalié A, Philipp SE, Zhu MX, Helms V, Wissenbach U, Flockerzi V. Conserved gating elements in TRPC4 and TRPC5 channels. J Biol Chem. 2013;288:19471-19483.

11. Ko J, Myeong J, Yang D, So I. Calcium permeability of transient receptor potential canonical (TRPC) 4 channels measured by TRPC4GCaMP6s. Korean J Physiol Pharmacol. 2017;21:133-140.

12. Rodrigues T, Sieglitz F, Somovilla VJ, Cal PM, Galione A, Corzana F, Bernardes GJ. Unveiling (-)-englerin A as a modulator of L-type calcium channels. Angew Chem Int Ed Engl. 2016;55:11077-11081.

13. Okada T, Shimizu S, Wakamori M, Maeda A, Kurosaki T, Takada N, Imoto K, Mori Y. Molecular cloning and functional characterization of a novel receptor-activated TRP $\mathrm{Ca}^{2+}$ channel from mouse brain. $J$ Biol Chem. 1998;273:10279-10287.

14. Jung S, Mühle A, Schaefer M, Strotmann R, Schultz G, Plant TD. Lanthanides potentiate TRPC5 currents by an action at extracellular sites close to the pore mouth. J Biol Chem. 2003;278:3562-3571.

15. Gross SA, Guzmán GA, Wissenbach U, Philipp SE, Zhu MX, Bruns $\mathrm{D}$, Cavalié A. TRPC5 is a $\mathrm{Ca}^{2+}$-activated channel functionally coupled to $\mathrm{Ca}^{2+}$-selective ion channels. J Biol Chem. 2009;284:3442334432 . 
16. Philipp S, Cavalié A, Freichel M, Wissenbach U, Zimmer S, Trost C, Marquart A, Murakami M, Flockerzi V. A mammalian capacitative calcium entry channel homologous to Drosophila TRP and TRPL. EMBO J. 1996;15:6166-6171.

17. Gees M, Colsoul B, Nilius B. The role of transient receptor potential cation channels in $\mathrm{Ca}^{2+}$ signaling. Cold Spring Harb Perspect Biol. 2010;2:a003962.

18. Ludlow MJ, Gaunt HJ, Rubaiy HN, Musialowski KE, Blythe NM, Vasudev NS, Muraki K, Beech DJ. (-)-Englerin A-evoked cytotoxicity is mediated by $\mathrm{Na}^{+}$influx and counteracted by $\mathrm{Na}^{+} / \mathrm{K}^{+}$-ATPase. $J$ Biol Chem. 2017;292:723-731.

19. Muraki K, Ohnishi K, Takezawa A, Suzuki H, Hatano N, Muraki Y, Hamzah N, Foster R, Waldmann H, Nussbaumer P, Christmann $\mathrm{M}$, Bon RS, Beech DJ. $\mathrm{Na}^{+}$entry through heteromeric TRPC4/C1 channels mediates (-)Englerin A-induced cytotoxicity in synovial sarcoma cells. Sci Rep. 2017;7:16988.

20. Duan J, Li J, Zeng B, Chen GL, Peng X, Zhang Y, Wang J, Clapham DE, Li Z, Zhang J. Structure of the mouse TRPC4 ion channel. Nat Commun. 2018;9:3102.

21. Vinayagam D, Mager T, Apelbaum A, Bothe A, Merino F, Hofnagel O, Gatsogiannis C, Raunser S. Electron cryo-microscopy structure of the canonical TRPC4 ion channel. Elife. 2018;7. pii: e36615.

22. Semtner M, Schaefer M, Pinkenburg O, Plant TD. Potentiation of TRPC5 by protons. J Biol Chem. 2007;282:33868-33878.

23. Carson C, Raman P, Tullai J, Xu L, Henault M, Thomas E, Yeola S,
Lao J, McPate M, Verkuyl JM, Marsh G, Sarber J, Amaral A, Bailey S, Lubicka D, Pham H, Miranda N, Ding J, Tang HM, Ju H, et al. Englerin A agonizes the TRPC4/C5 cation channels to inhibit tumor cell line proliferation. PLoS One. 2015;10:e0127498.

24. Rubaiy HN, Seitz T, Hahn S, Choidas A, Habenberger P, Klebl B, Dinkel K, Nussbaumer P, Waldmann H, Christmann M, Beech DJ. Identification of an (-)-englerin A analogue, which antagonizes (-)-englerin A at TRPC1/4/5 channels. Br J Pharmacol. 2018;175:830839.

25. Chen X, Li W, Riley AM, Soliman M, Chakraborty S, Stamatkin CW, Obukhov AG. Molecular determinants of the sensitivity to $\mathrm{G}_{\mathrm{q} / 11}$-phospholipase C-dependent gating, $\mathrm{Gd}^{3+}$ potentiation, and $\mathrm{Ca}^{2+}$ permeability in the transient receptor potential canonical type 5 (TRPC5) channel. J Biol Chem. 2017;292:898-911.

26. Duan J, Li J, Chen GL, Xie K, Peng X, Zhou W, Zhong J, Zhang Y, Xu J, Xue C, Zhu L, Liu W, Tian XL, Wang J, Zeng B, Clapham DE, Li Z, Zhang J. Cryo-EM structure of the receptor-activated TRPC5 ion channel at 2.9 angstrom resolution. bioRxiv. 2018;2018:467969.

27. Li J, Zhang X, Song X, Liu R, Zhang J, Li Z. The structure of TRPC ion channels. Cell Calcium. 2019;80:25-28.

28. Kim H, Kim J, Jeon JP, Myeong J, Wie J, Hong C, Kim HJ, Jeon $\mathrm{JH}$, So I. The roles of G proteins in the activation of TRPC4 and TRPC5 transient receptor potential channels. Channels (Austin). 2012;6:333-343. 